\title{
Effect of Supplementation of Neem (Azadirachta indica) Leaf Powder on Growth Performance and Carcass Characteristics of Broilers
}

\author{
P. D. Mali", S. B. Adangale, N. Sharma, Y. G. Fulpagare and S. S. Patale \\ Department of Animal Husbandry and Dairy Science, Post Graduate Institute, Mahatma \\ Phule Krishi Vidyapeeth, Rahuri, Maharashtra-413 722, India \\ *Corresponding author
}

\section{A B S T R A C T}

\begin{tabular}{l} 
K e y w o r d s \\
Broilers, Neem leaf \\
powder, \\
Supplementation, \\
Growth \\
performance, \\
Carcass \\
characteristics \\
\hline Article Info \\
$\begin{array}{l}\text { Accepted: } \\
\text { 04 September } 2020 \\
\text { Available Online: } \\
\text { 10 October } 2020\end{array}$ \\
\hline
\end{tabular}

The present study was conducted to evaluate the effect of supplementation of Azadirachta indica leaf powder on growth performance of broilers. A One hundred and sixty, day-old broiler chicks (Ven Cobb) were procured and randomly distributed in to four treatments. Growth trial was conducted in a completely randomized design comprising four dietary treatments. The control $\left(\mathrm{T}_{0}\right)$ group was fed standard ration and treatment $\mathrm{T}_{1}, \mathrm{~T}_{2}$ and $\mathrm{T}_{3}$ group were provide standard ration supplemented with neem leaf powder (NLP) @ $5 \mathrm{gm}, 10 \mathrm{gm}$ and $15 \mathrm{gm} / \mathrm{kg}$ of broiler ration respectively. The result showed that improvement in live body weight with the inclusion of neem leaf powder in the ration. The significantly higher $(\mathrm{p}<0.05)$ weekly body weight was observed in treatment group $\mathrm{T}_{2}$ compared to those in $\mathrm{T}_{0}, \mathrm{~T}_{1}$ and $\mathrm{T}_{3}$ group. The birds fed with $10 \mathrm{gm} / \mathrm{kg}$ feed NLP recorded significantly higher mean weight gain compared to control and other treatment groups. The overall feed intake of the birds showed non-significant differences in all the treatment groups for the entire experimental period. The feed conversion ratio among the all treatment groups was found to be better compared to control. No significant $(\mathrm{p}>0.05)$ influence was observed in carcass parameters like dressing yield and giblet yield (liver, heart and gizzard) in all treatment groups. The results from the present study, it could be concluded that supplementation of neem leaf powder in broiler diet at $10 \mathrm{~g} / \mathrm{kg}$ of feed as it proved be significantly better growth performance, feed intake and feed conversion ratio.

\section{Introduction}

Today poultry industry is one of the fastest growing segments of the agricultural. Poultry is major source of meat in India. Use of feed additives like antibiotics and others have residual effect and these are most expensive. To avoid the harmful effects of chemical feed additives on human body due to its indiscriminate use, the nutritionist all over the world are trying to find the phytogenic feeds additives for betterment in production.

Many plants have beneficial multifunctional aspects which are derived from their specific bio-active components (Kamel 2000). One of such plants Neem Azadirachta indicais evergreen, non-leguminous multipurpose tree belongs to family Meliaceae and widely distributed in Asia, Africa and other tropical 
parts of the world (Sombatsiri et al., 1995). Neem leaves contain crude protein $15.8 \%$, crude fibre $14.6 \%$, Ether Extract 8.5\%, Ash 4.5\%, Moisture $13.0 \%$, NFE $56.6 \%$ (Bonsu et $a l ., 2012)$. These percentages vary from one place to another. More than one hundred and thirty-five bio-active compounds have been isolated from different parts of neem trees including azadichtin, meliacin, gedunin, salanin, nimbin, valassin, sodium nimbolide, cyclic trisulphides etc. The neem leaf exhibits a wide range of pharmacological activities viz., anti-inflammatory, anti-hyperglycaemic, anti-ulcer, anti-malarial, anti-fungal, antibacterial, anti-viral, anti-oxidant, antimutagenic, immunomodulatory and various others properties without showing any adverse effects (Supriya and Nagini, 2005). Therefore, considering the vast benefits of the neem the present study has been undertaken to evaluate the performance and carcass parameters of broiler chickens.

\section{Materials and Methods}

The trial was conducted on 160 day old, vencobb-400 broiler chicks at Poultry Unit, veterinary Polyclinic and AI Center MPKV, Rahuri - 413722, Dist. Ahmednagar, Maharashtra. The 160 birds were divided in to 4 treatments groups and housed under deep litter system. The $\mathrm{T}_{0}$ birds were fed on a basal ration (Control), $\mathrm{T}_{1}$ Basal ration $+5 \mathrm{gm}$ NLP $/ \mathrm{kg}$ of feed, $\mathrm{T}_{2}$ Basal ration $+10 \mathrm{gm}$ NLP/ $\mathrm{kg}$ of feed and $\mathrm{T}_{3}$ basal ration $+15 \mathrm{gm} \mathrm{NLP} / \mathrm{kg}$ of feed. Immediately arrival of chicks was weighed and distributed randomly in to 4 treatment groups viz, $\mathrm{T}_{0}, \mathrm{~T}_{1}, \mathrm{~T}_{2}$ and $\mathrm{T}_{3}$ with 40 chicks in each group, on body weight basis.

Body weight and feed consumption were recorded at weekly interval up to $6^{\text {th }}$ weeks of age. Feed conversion efficiency was estimated as quantity $(\mathrm{kg})$ of feed consumed for every $\mathrm{kg}$ gain in body weight.
Performance efficiency (\%) was calculated as the ratio of body weight $(\mathrm{kg})$ and feed conversion efficiency (kg), multiplied by 100 . At the end of trial, three birds from each group were randomly selected and slaughtered for estimating dressing percentage.

\section{Statistical analysis}

Proximate composition of broiler ration and feed additives analysis was carried out as per the method given in A. O. A. C., 2005. The data were analysed by standard statistical techniques (Snedecor and Cochran, 1994).

\section{Results and Discussion}

The data pertaining to growth performance and allied traits as influenced by neem leaf powder supplementation in broiler chickens are elucidated here under.

\section{Chemical composition of experimental feed ingredients (\% DM basis)}

The experimental feed viz. broiler starter and finisher which were supplemented with neem leaf powder as per treatment details. The proximate composition of the rations is presented in Table 1.

\section{Starter ration}

The crude protein, crude fibre, ether extract, total ash, nitrogen free extract and acid insoluble ash of starter ration were 23.00, $4.60,4.80,7.20,60.40$ and 1.25 per cent respectively and calculated metabolizable energy (ME) of the diet was $2863.11 \mathrm{Kcal} / \mathrm{kg}$.

\section{Finisher ration}

The crude protein, crude fibre, ether extract, total ash, nitrogen free extract and acid insoluble ash of finisher ration were 20.00, 
$3.78,4.30,6.85,65.15$ and 1.44 per cent respectively and calculated metabolizable energy (ME) of the diet was $2939.75 \mathrm{Kcal} / \mathrm{kg}$.

\section{Body weight changes (g)}

The average body weight of broilers under different treatment groups differed significantly $(\mathrm{p}<0.05)$. The significantly $(\mathrm{P}<0.05)$ higher body weight was observed in treatment group $\mathrm{T}_{2}(1928.35 \pm 16.45)$ fed
NLP $10 \mathrm{~g}$ per $\mathrm{kg}$ feed. The results of present study were similar with Manwar et al., (2007) supplemented neem leaf powder @ 1-2 gm/kg feed and reported significant increase in the live body weight of broilers in the neem fed groups when compared with control group. Results are in agreement with Khan etal. (2014) who observed that broilers fed $1 \%$ neem seed cake showed significantly $(\mathrm{p}<$ 0.05 ) higher body weights at six weeks of age over those of the control group (Table 2).

Table.1 Percent proximate composition of experimental broiler ration on dry matter basis

\begin{tabular}{|l|c|c|}
\hline \multirow{2}{*}{ Nutrients } & \multicolumn{2}{|c|}{ Broiler ration } \\
\hline Crude protein & Starter & Finisher \\
\hline Crude fiber & 23.0 & 20.0 \\
\hline Ether extract & 4.60 & 3.78 \\
\hline Total ash & 4.80 & 4.3 \\
\hline Nitrogen free extract & 7.20 & 6.85 \\
\hline Acid insoluble ash & 60.40 & 65.15 \\
\hline ME $(\mathrm{kcal} / \mathrm{kg})$ & 1.25 & 1.44 \\
\hline
\end{tabular}

Table. 2 Broilers traits in different groups of chicks up to $6^{\text {th }}$ weeks of age

\begin{tabular}{|l|l|l|l|l|}
\hline Treatment & Body Weight & Weight Gain & Feed Intake & FCR \\
\hline $\mathbf{T}_{\mathbf{0}}$ & $1764.65 \pm 14.72^{\mathrm{a}}$ & $405.58 \pm 11.82^{\mathrm{a}}$ & $960.03 \pm 9.03$ & $1.96 \pm 0.02^{\mathrm{c}}$ \\
\hline $\mathbf{T}_{\mathbf{1}}$ & $1849.30 \pm 13.43^{\mathrm{b}}$ & $425.98 \pm 12.97^{\mathrm{ab}}$ & $952.75 \pm 10.94$ & $1.88 \pm 0.01^{\mathrm{b}}$ \\
\hline $\mathbf{T}_{\mathbf{2}}$ & $1928.35 \pm 16.45^{\mathrm{c}}$ & $458.75 \pm 14.24^{\mathrm{b}}$ & $946.25 \pm 13.77$ & $1.80 \pm 0.02^{\mathrm{a}}$ \\
\hline $\mathbf{T}_{\mathbf{3}}$ & $1869.90 \pm 17.72^{\mathrm{b}}$ & $445.78 \pm 17.35^{\mathrm{ab}}$ & $950.55 \pm 12.79$ & $1.86 \pm 0.02^{\mathrm{b}}$ \\
\hline
\end{tabular}

Values bearing different superscripts in column differ significantly $(\mathrm{p}<0.05)$

Table.3 Effect of supplementation of neem leaf powder on carcass traits

\begin{tabular}{|l|l|l|l|l|l|l|}
\hline Treatment & Live weight $\mathbf{( g )}$ & $\begin{array}{l}\text { Dressing } \\
\text { weight }(\mathbf{\%})\end{array}$ & Breast (\%) & Giblet (\%) & $\begin{array}{l}\text { Drumstick } \\
(\mathbf{\%})\end{array}$ & Thigh (\%) \\
\hline $\mathbf{T}_{\mathbf{0}}$ & $1861 \pm 19.71$ & $67.22 \pm 1.35$ & $20.75 \pm 0.83$ & $4.89 \pm 0.20$ & $13.35 \pm 0.50$ & $11.88 \pm 0.40$ \\
\hline $\mathbf{T}_{\mathbf{1}}$ & $1920.5 \pm 21.02$ & $68.38 \pm 0.28$ & $20.97 \pm 0.86$ & $4.75 \pm 0.19$ & $13.68 \pm 0.12$ & $12.04 \pm 0.58$ \\
\hline $\mathbf{T}_{\mathbf{2}}$ & $1960.33 \pm 31.08$ & $69.94 \pm 0.45$ & $21.00 \pm 1.18$ & $4.53 \pm 0.23$ & $13.78 \pm 0.61$ & $13.25 \pm 0.44$ \\
\hline $\mathbf{T}_{\mathbf{3}}$ & $1934.17 \pm 34.24$ & $67.77 \pm 0.44$ & $20.26 \pm 1.13$ & $4.43 \pm 0.18$ & $13.33 \pm 0.20$ & $13.17 \pm 0.24$ \\
\hline
\end{tabular}

\section{Body weight gain $(\mathrm{g})$}

The average gain in body weight in treatment $\mathrm{T}_{2}(458.75 \pm 14.24)$ group was significantly
( $\mathrm{P}<0.05 \%)$ higher. Then followed by $\mathrm{T}_{3}$ (445.78 \pm 17.35$), \mathrm{T}_{1}(425.98 \pm 12.97)$ and $\mathrm{T}_{0}$ $(405.58 \pm 11.82)$. The results obtained in the study corresponds with the results of Sarkar $e t$ 
al., (2014) observed that broilers supplemented with $1 \%$ neem leaves extract (Group A, C and D) gained the significantly higher $(p<0.001)$ live weight compared to untreated control group regardless of calibacillosis induction. These results are in agreement with Khatun et al., (2013) revealed that supplementation 1-3 ml of tulsi and neem leave extract per kg poultry ration increase in live body weight and improvement in weekly gain in weight and feed efficiency as compared to that control group of poultry.

\section{Cumulative feed consumption (g)}

The overall feed intake of the birds showed non-significant differences in all the treatment groups for the entire experimental period. The treatment $T_{2}$ showed lower feed consumption and highest in control. The trend indicated that the decline in feed intake with an increase in the level up to $15 \mathrm{gm}$ per $\mathrm{kg}$ of feed, supplementation of neem leaf powder was recorded during the experiment. This might be due to presence of miliacin which forms bitter principles of leaves (National Research Council, 1994). A similar finding is reported by Khan et al., (2014) was showed that broiler in control group consumed high feed quantity and it was decreased significantly in group C birds fed to $1 \%$ level of neem seed cake.

\section{Feed Conversion ratio}

The better feed conversion ratio from first to sixth week ranged from 1.80 to 1.96 which was significantly $(p<0.05)$ better feed conversion ratio of 1.80 obtained in $\mathrm{T}_{2}$ group followed in T3, T1 group and poor in feed conversion i.e. 1.96 in T0 control at the end of $6^{\text {th }}$ week. The result of present study supports the findings of similarly Abujradah et al., (2018) offered basal diet supplemented with probiotic + garlic + neem leaf @ $1 \mathrm{~kg}$ per ton of feed to which they get the best performance $(\mathrm{p}<0.05)$ in final body weight, weekly gain, weekly feed intake and feed conversion ratio. The results obtained are contrary to the findings of Alam et al., (2015) found identical non-significant FCR in all neem treated groups compared to that of control group of broilers.

\section{Carcass traits}

The carcass characteristics and cut-up part of broiler chickens fed dietary levels of neem leaf powder are presented in Table 3. The average dressing percentage mong the different treatment groups varied between $67.22 \pm 1.35$ to $69.94 \pm 0.45$ percent. The differences among all treatment groups were non-significant. The breast yield was highest in the $\mathrm{T}_{2}$ group. However, the difference among all the treated groups was nonsignificant. Although a slight variation was observed in giblet and drum stick per cent of the carcass weight of different treatment groups, it was statistically non-significant. Thigh yield was highest in the $T_{2}$ group. However, the difference among all treatments was non-significant. Results are in agreement with Kharde et al., (2014) who observed no significant $\quad(p>0.05) \quad$ influence of supplementation of garlic and neem leaf powder (NLP) on carcass parameters like dressing yield and giblet yield (heart, gizzard and liver) in all treatment groups.

\section{References}

Abujradah, M.K., Neeraj and Pandey, R. (2018) Effect of probiotics, Garlic and Neem leaf powder supplementation on feed efficiency in caged broiler. Int.J.Curr.Microbiol.App.Sci. 7(6):7883.

Alam, M., Rakib, F. K., AI-Hasan, A., Hasan, S. and Ali, A. (2015). Effects of neem leaf powder as a growth promoter in broiler. International Journal of 
Natural and Social Science2:22-26.

AOAC. 2005. Official method of Analysis. 18th Edition, Association of Officiating Analytical Chemists, DC, Method 935.14 and 992.24

Bonsu, F.R., Kagya-Agyemang, J.K., Kwenin, W.K. and Zanu, H.K. (2012). Medicinal response of broiler chicken to diets containing Neem (Azadirachta indica) leaf meal, haematology and meat sensory analysis. World Applied Science Journal 19(6): 800805.

Kamel, C. (2000). A novel look at a classic approach of plant extracts. Feed Mix 8:16-17.

Khan, S.A., Ahmed, I., Hussain, A., Sabir, N., Ahmed, G. and Awan, K. (2014). Effect of supplementation of ration with neem seed cake on the growth of broilers. Global Veternaria13(3):414418.

Kharade, K.R. and Soujanya, S. (2014). Effect of garlic and neem leaf powder supplementation on growth performance and carcass traits in broilers. Veterinary World. 7(10): 799-802.

Khatun, S., Mostofa, M., Alom, F., Uddin, J., Alam, M.N. and Moitry, N.F. (2013). Efficiency of tulsi and neem leaves extract in broiler production. Bangladesh Journal Veterinary Medicine 11(1):1-5.
Manwar, S.J., Thirumurugan, P., Konwar, D., Chidanandaiah and Karna, D.K. (2007). Effect of Azadirachta indica leaf powder supplementation on broiler performance. Indian Veterinary Journal. 84:159-162.

National Research Council (NRC) (1994). Neem: a tree for solving global problems. Washington, DC: National Academy Press.

Sarkar, S.K., Mostofa, M., Akter, F., Rahman, M.M. and Sultanas, M.R. (2014). Effects of aqueous extract of neem (Azadirachta indica) leaves as growth promoter and anti-colibacillus in broilers. Bangladesh. Journal of Animal Science 43(2):138-141.

Snedecor, G.W. and Cochran, W.G. (1994). Statistical Methods, $8^{\text {th }}$ edn.Affiliated East-West press Pvt. Ltd., New Delhi, India.

Sombatsiri, K., Ermel, K. and Schumuttered, H. (1995). Other Meliaceous Plants Containing Ingredients for Integrated Pest Management and Further Purpose. In: Schmutter, H. (Ed.), Neem Tree Azadirachta indica Azadirachta juss and Other Meliaceous Plants VCH, Germany, pp. 585-597.

Subapriya, R. and Nagini, S. (2005). Medicinal properties of neem leaves: a review. Current Medicinal Chemistry Anticancer Agents. 5:149-156.

\section{How to cite this article:}

Mali, P. D., S. B. Adangale, N. Sharma, Y. G. Fulpagare and Patale, S. S. 2020. Effect of Supplementation of Neem (Azadirachta indica) Leaf Powder on Growth Performance and Carcass Characteristics of Broilers. Int.J.Curr.Microbiol.App.Sci. 9(10): 70-74. doi: https://doi.org/10.20546/ijcmas.2020.910.010 